\title{
Against Reactionary Populism: Opening a Needed Conversation in Education
}

\author{
Guest Editors \\ Christopher G. Robbins, Eastern Michigan University; Email: crobbin2@emich.edu \\ Joe Bishop, Eastern Michigan University; Email: joe.bishop@emich.edu
}

\section{Editor-in-Chief}

Bulent Tarman

In the early throes of the U.S. counter-cultural movement of the 1960s, Bob Dylan sang, "You don't need a weatherman to know which way the wind blows." Less a critique of experts than a commentary on the observable cross-currents in U.S. (and global) politics and culture at the time, Dylan slyly paid homage to the capacities of average citizens to find their own way through the mess, while indicting a heavy-handed government consolidating power in a world gone wrong. Like then, we find ourselves in a world that is seemingly going wrong at every turn and with no dearth of heavy-handed governments. We see this each time we compulsively reach for our phones or turn on our computers, get our daily drip of division, distraction, or news (a 24/7 version of the two minutes of hate in Orwell's 1984 coupled with a steady supply of soma from A Brave New World), check our feeds, or resend someone's 150 characters of revelation. If these things fail to satiate one's penchant for pain or desire to confirm the end times, then we can get a concentrated version of the malaise when the person in the position of president of the U.S. tweets, often multiple times per day, an alphabet soup of very rarely coded nativism, isolationism, conspiracy theories, and wounded white male entitlement. Unlike the time in which the young Dylan briefly railed, it seems we would not trust the insight of a meteorologist (or any expert, for that matter) even when we need it, much less have a basic hope in the capacities of others to help us through the thicket that is the current political and cultural landscape. Or, so we are instructed: Be afraid, be distrustful and, most of all, be aggrieved. 
We live in a time of fracture. Consider some recent data of U.S. voters' views: $73 \%$ of Democrat and Republican voters disagree on both policy ideas and basic facts, whereas only $26 \%$ can agree on facts even if they differ on policy positions (Pew Research Center, 2019). In a nation known globally for its bloated and racially imbalanced prison system, 71\% of Democrats believe that the criminal justice system unfairly treats racial and ethnic minorities, while $10 \%$ of Republicans hold the same belief (Pew Research Center, 2018). What about views on gun violence in a nation known for exceedingly high unnecessary deaths from guns, in which children and adults from all parties die from gun violence? Seventy-seven percent of Democrats and $34 \%$ of Republican think gun laws need to be stricter (Newport \& Dugan, 2017). The list could grow with indicators for virtually every issue related to healthcare, immigration, military spending, government regulation of markets, environment, women's rights and abortion, workers' rights, and higher education.

We also live in a time of regression. After four decades of neoliberal economics in Western countries, and an especially cruel modality of U.S. neoliberalism, angst justifiably exists across the political spectrum. This, no matter the political position, is something on which people can agree. Considerable common ground, cause, and objective between rival teams disappear beyond this easy observation, putting the teams in seemingly incommensurable oppositions. The teams not only play on different fields, they pursue radically different objectives informed by equally varying logics, evidenced in part by the teams' inability to agree on basic facts or see the same reality. On the left, "networked" participatory social movement forms attempt to challenge a host of issues ranging from class inequality and police brutality to LGBTQQI+ rights and militarism (see della Porta, 2017). Alternately, the down-trodden and aggrieved on the right see no irony in finding common cause with (often well-heeled) charismatic leaders who speak to "the people," while adding insult to injury for the working classes as the leaders advance tax codes and trade laws that further pinch a lower-middle- and working class still trying to rebound after decades of stagnating wages and the crushing recession of 2008. Here, the villain is not "government," per se, as the claims would suggest, but rather a government that, under the spell of a digitally-driven info-/finance economy, seems to favor all but whites (straight, G-d-fearing ones). So the excitement builds around "tough," usually male leaders who promise to return the polity to a mythical past wherein hardworking people prevail and achieve 
the dreams they perceive others (e.g., educated "Others" in the U.S.) to have taken from them with the help of the government (see Fraser, 2017; Hochschild, 2016). Consequently, the government acts less as a conduit through which citizens negotiate competing claims and visions than a hinge point on which contemporary angst swings, arcing for the past decade toward one that operates on unabashedly militaristic, xenophobic, racist, and sexist principles. Difference has become one group's fodder for participatory forms of democracy, another's existential threat around which to foster exclusionary politics in the name of a narrowly defined "people."

Such a tension raises essential questions about not only the durability and elasticity of liberal, representative democracy and civic engagement, but also how people learn to live with this contemporary antagonism and, importantly, with and for each other. Democracy cannot survive without this foundation. Outside of an insightful run of books by Giroux over the past two decades, very little has been said about the role of schooling and education, more broadly, in challenging the great fracture and regression. This special issue seeks, admittedly in a modest way, to begin broader conversations about the role of schooling and education in enriching democracy and challenging reactionary populisms.

Krynski opens the issue on this very point. Richly weaving deep democratic theory and contemporary theories of voice, Krynski ponders the state-the government and our human condition-as one of inherent fragility. The state and the human condition are arrangements that rely on a delicate balance of state authority and people power. How should this power be formed, articulated, and deployed? Where do schools fit in this articulation? Krynski explores the unfulfilled democratic mission of public schools, even in their imperiled state and contradictory relationship to the state, to envision a collective way forward and the formation of a larger swath of common ground on which to make claims and negotiate interests.

Not a rebuttal to Krynski but a measured consideration of one of many serious school challenges we would have to address in re-forming and re-articulating public schools with the public, Ferris considers the institutional and embodied forms that the politics of fear and antagonism have taken in these fractured times. A challenging analysis that should provoke considerable conversation, Ferris analyzes school responses to violence. In particular, he 
considers the use of the ALICE training model, explicitly raising questions about how its form and logic either reinforce or install dangerous binaries of perpetrator-victim, short-circuiting and bypassing more democratic forms of community-building and safety provision in school contexts. Still, something should be done to protect students and their school communities. If it is not rearguard responses to violence, then what should schools and communities (and society more generally) do in the provision of safety, while being sensitive to the powerful pedagogies and socialization at work in school responses to violence?

In "Disrupting Standardization with Food and Love," Grewal et al. put the reader in the space of "place." Despite, maybe even in spite of, the power of rigid, market-based forms of school standardization to influence the formation of hierarchical, competitive, and individualistic relationships, the ways that we actually form and nurture our relationships, in the place we actually live, matters greatly. How do we ritualize our relationships? What role does the act of learning how to love others while communing with them possibly play in grounding us in social forms that defy not only anti-democratic relationships in schools but also the fracture we have come to think exists everywhere outside our doors, across the world, and in the tiny screen in the palm of our hands? This is not a solution to the regression and fracture, but it surely provides a significant starting point: two basic needs that have no partisan boundaries - the need to be nourished and the need to be loved, while calling upon us to reconsider our ethical obligation to love the Other.

Snounu, in "Disability and Higher Education in Palestine: Models of Resilience and Inclusion in the Face of Segregating Democracy," examines practices of deliberate maiming of indigenous Palestinians in a context permeated by local and international politics as they play out in Gaza and the West Bank. In particular, she draws our attention to the ethics of care higher education professionals rely on as they teach and administer under what are considered apartheid conditions in an occupied territory. She asks us to think about how intentional maiming impacts the development of an ethic of care. She also asks: How might a progressive pedagogy be implemented in such conditions? What role does flexibility play in accommodating and advocating for disabled students? What might resilience look like in these new colonial situations? Perhaps an ethic of care is one way we might start repairing contemporary fractures. 
While Benegas, in "Teacher Proof: The Intersection of Scripted Curriculum and Culturally Relevant Pedagogy for English Learners," also considers the sociopolitical climate impacting teaching, unlike Snounu, she focuses on the current accountability and standardization climate in schools as she examines the experience of four student teachers implementing a scripted reading curriculum in an ethnically diverse elementary school. By considering policies, themselves the result of external bodies, readers are asked to consider relationships between structure and practice. The results of her study ask us to consider the cultural relevance of scripted curricula. Furthermore, she asks how is it that teachers deal with fear and nonnegotiables imposed by district administrators as a result of adopting scripted constraints. Her conclusion that mandated standardization inhibits the use of culturally relevant pedagogy for English learners suggests also that standardization negatively influences all learners.

Mason, in "Dewey and Political Communication in the Age of Mediation," rounds out this issue by drawing our attention to the plethora of information bombarding us in the current sociopolitical environment. He draws from Dewey and Lippmann to offer a set of ideas which we might use to negotiate the quagmire of mediated communication. As he notes, for Dewey, meaning is actively constructed in the communication process among people rooted locally and directly participating, because, for both Dewey and Lippman, mediated interactions make it easier to manipulate a population. Given that these impoverished communications fostered by mediated interactions seem to play a strong role in maintaining our fractured state of affairs, we are asked to think about how education should respond, and we should turn to Dewey for a way to reconsider the speed of schooling and educating for media literacy in order to envision an alternate way of living and interacting for the future. 


\section{References}

della Porta, D. (2017). Progressive and regressive politics in late neoliberalism. In H. Geiselberger (Ed.), The great regression (pp. 26-33). Malden, MA: Polity.

Fraser, N. (2017). Progressive neoliberalism versus reactionary populism: A Hobson's choice. In H. Geiselberger (Ed.), The great regression (pp. 40-48). Malden, MA: Polity.

Hochschild, A. (2016). Strangers in their own land: Anger and mourning on the American right. New York, NY: The New Press.

Newport, F., \& Dugan, A. (2017). Partisan differences growing on a number of issues. Gallup. Retrieved October 5, 2019, from https://news.gallup.com/opinion/pollingmatters/215210/partisan-differences-growing-number-issues.aspx

Pew Research Center. (October, 2018). Little partisan agreement on the pressing problems facing the U.S. Retrieved September 30, 2019, from https://www.peoplepress.org/2018/10/15/little-partisan-agreement-on-the-pressing-problems-facing-theu-s/

Pew Research Center. (October 10, 2019). Partisan antipathy: More intense, more personal. Retrieved November 4, 2019, from https://www.peoplepress.org/2019/10/10/partisan-antipathy-more-intense-more-personal/ 